\title{
Left main bronchus compression by aneurysm and kinking of the descending aorta
}

\author{
Andrey Slautin, Vladimír Mikulenka, Jaroslav Hlubocký, Jaroslav Lindner
}

\author{
2nd Department of Surgery - Department of Cardiovascular Surgery, First Faculty of Medicine, Charles University \\ and General University Hospital in Prague, Prague
}

ARTICLE HISTORY:

Submitted: 13. 1. 2021

Accepted: 7. 2. 2021

Available online: 2. 12. 2021

\section{Klíčová slova:}

Aneurysma aorty

Kinking aorty

Komprese bronchu

\section{SOUHRN}

Představujeme kazuistiku 71leté pacientky s kompresí levého hlavního bronchu aneurysmatem descendentní aorty, která se projevila progresivní dušností, kašlem a hemoptýzou bez prítomnosti teploty. Osobní anamnéza pacientky zahrnuje opakované respirační infekce, chronický kašel, hospitalizaci pro levostrannou pneumonii. Během CT vyšetření bylo zjištěno aneurysma ascendentní aorty, dilatace a kinking descendentní aorty s útlakem levého hlavního bronchu. Zavedení stentu do bronchiálního lumen nemělo úspěch, proto byl u pacientky indikován chirurgický výkon, kdy byla provedena náhrada descendentní aorty. Útlak hlavního bronchu aneurysmatem a kinkingem aorty je velice vzácnou patologií. Jedinou možností léčby byl chirurgický zákrok.

(c) 2021, ČKS
Keywords:

Aneurysm of aorta

Bronchus compression

Kinking of aorta

\begin{abstract}
We hereby present a case report of airway compression due to descending aortic aneurysm occurred to 71-year-old female with 1-month progressive dyspnoea, haemoptysis, and cough without any fever. Her past medical history included repeated respiratory infections, chronic cough, an admission to the hospital 2 years ago due to left-side pneumonia. A dilatation of the ascending aorta and kinking of the descending aorta with compression of the left main stem bronchus was detected by the computed tomography. Stenting of the bronchial lumen had failed, and the patient was indicated for surgery, the descending aorta replacement had been performed. Left main stem bronchus compression of descending aorta kinking is a very rare pathology. Surgery was the only possible treatment.
\end{abstract}

\section{Introduction}

Vascular tracheobronchial compression syndrome can be congenital or acquired. Congenital type may present anomalies that are primarily asymptomatic and found incidentally during adulthood, or may cause symptoms only when the aorta becomes rigid due to atherosclerosis. Double aortic arch, right sided aortic arch, aberrant subclavian artery or malposition of pulmonary artery can cause significant compression of the trachea, main bronchi, and the oesophagus. The most common kind of acquired vascular tracheobronchial compression syndrome is aneurysm, ${ }^{1,2}$ a very rare cause is kinking of aorta. ${ }^{3}$ Here we present a case of aneurysm and kinking of the descending aorta leading to dyspnoea and recurrent pneumonias as a result of compression of the left main bronchus.

\section{Case report}

A 71-year-old female patient with history of repeated respiratory infections, chronic cough, and gradually progressive exertional dyspnoea (stops for breath after walking about 100-150 metres) was admitted for additional examination. She did not have a temperature or display laboratory signs of inflammation, a cardiac cause of shortness of breath was ruled out. Bi-plane chest radiography (Fig. 1) was performed; the cardiac shadow has an atypical shape with marked arching of the left contour corresponding to an extremely coiled course or aneurysm of the aorta. For this reason a computed tomography scan (Fig. 2) was added, where borderline dilation of the ascending aorta (STJ $36 \mathrm{~mm}$, ascending part $48 \mathrm{~mm}$ ) and aortic arch (35 $\mathrm{mm}$ ) were discovered, as was a sharp angulation of the di-

Address: MUDr. Andrey Slautin, 2nd Department of Surgery - Department of Cardiovascular Surgery, First Faculty of Medicine, Charles University and General University Hospital in Prague, U Nemocnice 499/2, 12808 Prague 2, e-mail: andrey.slautin@gmail.com

DOI: $10.33678 /$ cor.2021.024 


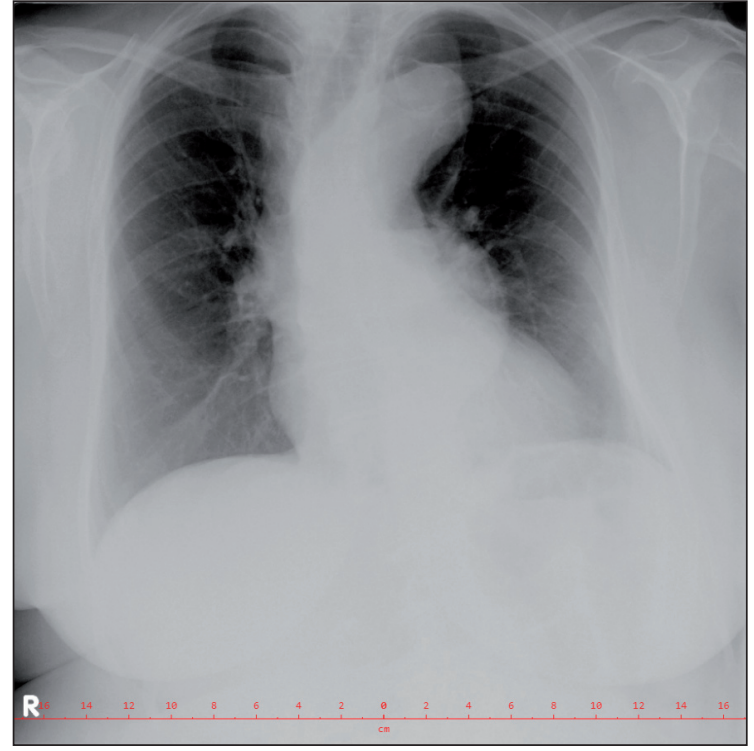

Fig. 1 - Bi-plane chest X-ray.

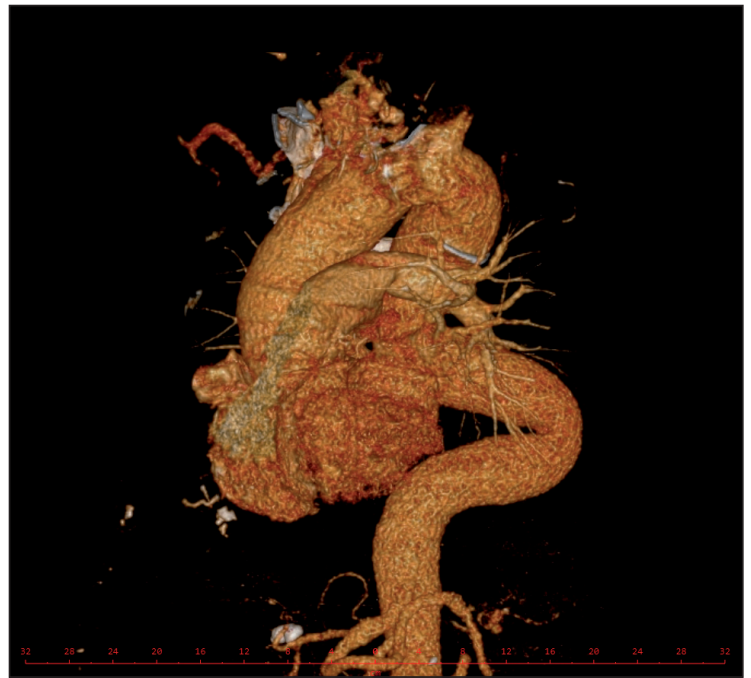

Fig. 2 - CT scan before surgery.

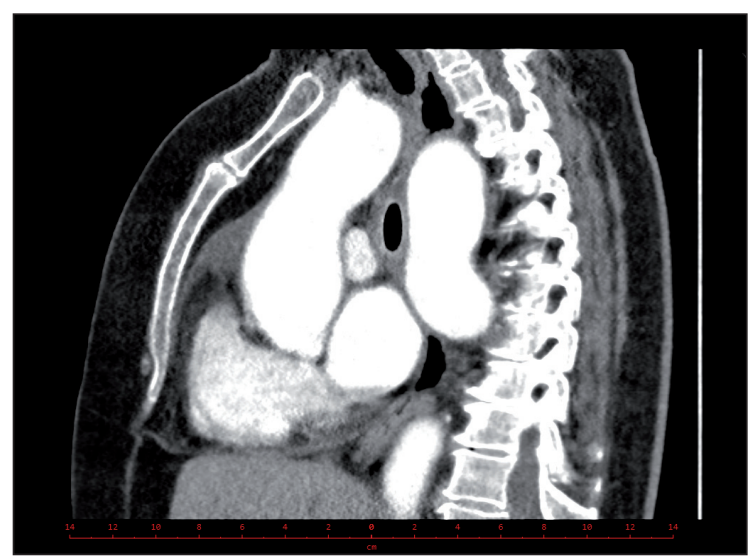

Fig. 3 - CT scan compression of bronchus.

lation of the descending aorta compressing the left main bronchus (Fig. 3). Spirometry did not indicate significant hypoventilation or an obstruction in the respiratory tract (saturation 98\%, Rf 80/min, FVC 84\%, FEV , 70\%, FEV 1

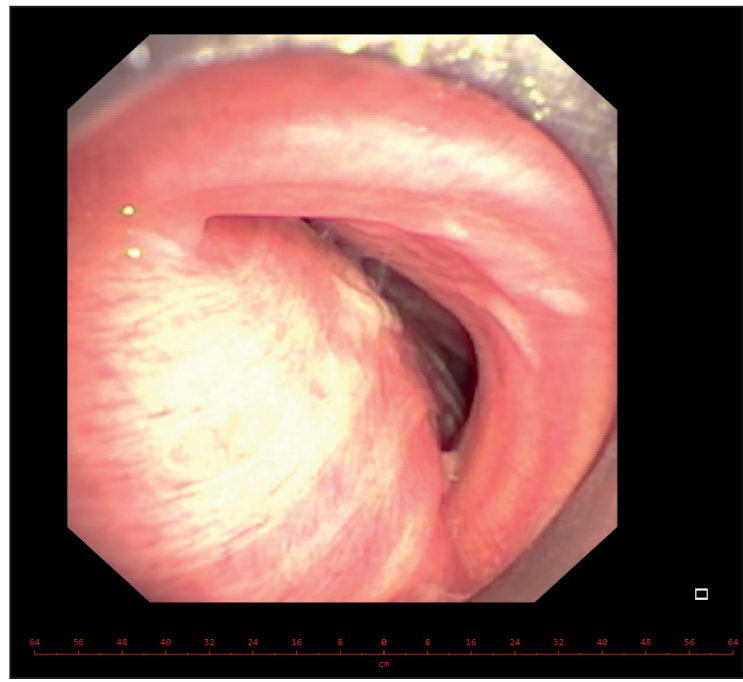

Fig. 4 - Bronchoscopy.

FVC 68,57 , PEF 76\%, Rtot 175\%, TLC 91\%, RV 115\%, TLCO $8,02 \mathrm{mmol} / \mathrm{KPA} / \mathrm{min}$ or $118 \%, \mathrm{KCO} 104 \%$, fast space : TLC $87 \%$, RV 115\%), bronchoscopy was indicated for an evaluation of the patency of the respiratory tract. During the examination a marked constriction of the left main bronchus and entire carina was discovered, significant from the ventilation aspect (Fig. 4). The state was evaluated as compression of the respiratory tract by aneurysm of descending aorta with its extreme angulation. Due to this angulation the finding could not be resolved by an endovascular intervention, so the patient was indicated for surgical treatment - replacement of descending aorta. Due to a significant risk of surgery, a decision was made to stent left main bronchus to improve respiratory functions and eliminate a potential focus of infection.

The bronchus was subsequently stented (Y-bifurcation stent Dumon $Y 18 \times 14 \times 14 \mathrm{~mm})$. After the stent insertion there was a short-term improvement in the general condition and difficulties subsided, but within a month

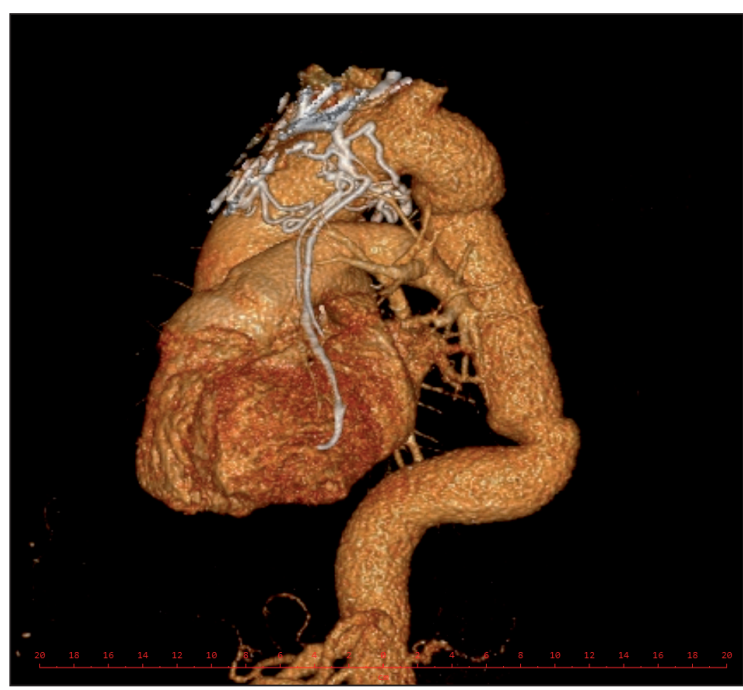

Fig. 5 - CT scan after surgery. 
there was another pulmonary inflammation. The situation demanded bronchoscopy again with the necessity of respiratory toilet for mucostasis inside the stent and in the periphery.

The operation was performed using selective double lumen intubation. From a left-sided thoracotomy descending aorta was exposed which is sigmoidally curved, pressing on the bronchus from the rear, medium dilated, above the diaphragm it is of normal dimensions. Left-side bypass performed with integrated oxygenator for ensuring sufficient oxygenation during operation (cannulation of left upper pulmonary vein and left common femoral artery). Descending thoracic aorta replaced by $30 \mathrm{~mm}$ Gelveawe prosthetic (Fig. 5).

Postoperatively repeated bronchoscopy, the 3rd postoperative day the stent was removed from left bronchus, toilet of the respiratory tract with subsequent improvement in ventilation (Fig. 6).

The patient was discharged in a stable state on the 25th postoperative day. There was a favourable finding in aorta during 6-month follow-up, the general state of the patient is good, shortness of breath NYHA II.

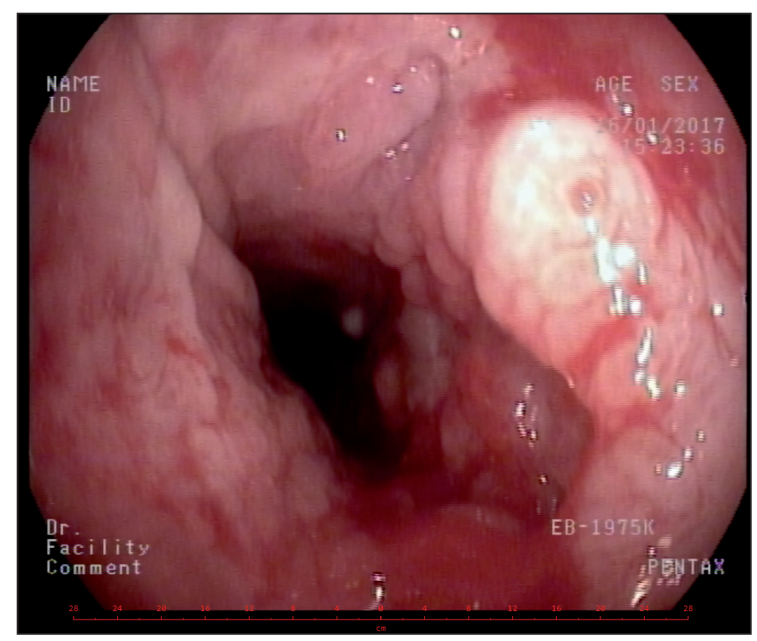

Fig. 6 - Bronchoscopy after stent explantation.

\section{Discussion}

Aneurysm of thoracic aorta is present in $0.01 \%$ of the adult population, of whom $30-40 \%$ have an aneurysm of the descending part of the aorta. Men and women have the same incidence of thoracic aortic aneurysm, but the age at diagnosis is a decade higher in women (approximately 70 years of age) than men (approximately 60 years of age) ${ }^{4,5}$

The most significant risk factors for the incidence of thoracic aortic aneurysm are atherosclerosis and arterial hypertension, congenital disorders of connective tissue. ${ }^{4-6}$

For the purposes of anatomical localisation of an aneurysm, a distinction is drawn between isolated aneurysms of the ascending aorta and arch (40\% of cases), isolated aneurysms of descending aorta (31\%), and combined $(29 \%) \cdot)^{4,5}$
Thoracic aortic aneurysms are often asymptomatic and diagnosed either by chance or in the case of an aortic dissection. Less frequently (5-10\% of cases) they could be diagnosed by large vessel compression symptoms (superior vena cava compression syndrome) or surrounding tissues (dysfunctions of $\mathrm{n}$. phrenicus or $\mathrm{n}$. recurrens), chest pain, cardiac murmurs.

In exceptional cases descending aortic aneurysm may become the cause of a bronchial obstruction that can manifest itself as a chronic cough, shortness of breath, haemoptysis, recurrent pneumonia, atelectasis. ${ }^{1,2,5-8}$

A possibility of treatment is the insertion of an expandable stent in the main bronchus, but in the view of the high external pressure of the aneurysm it can lead to the incidence of an aorto-bronchial fistula and fatal pulmonary bleeding during the insertion of the stent.9.10 There are other complications including granulation tissue formation, stent migration, metal fatigue, stent removal, mucus plugging, and halitosis. ${ }^{11}$ In this case the insertion of a bronchial stent was ineffective due to hypergranulation and mucostasis in stent.

Another possibility is the insertion of a stent graft in the descending aorta with subsequent reduction in bronchial compression, but due to kinking of the descending aorta we can predict this only with a great difficulty, and there is also a risk of progression of the compression of bronchus in the case of endoleak. Therefore resection of the thoracic part of the aorta was selected.

The surgical replacement of the descending aorta also eliminates external compression of bronchus and may constitute a radical solution of the problem.

\section{Conclusion}

Compression of the left main bronchus as a result of aneurysm and kinking of the descending aorta is a very rare pathology. In our case endotracheal treatment with insertion of expandable stent was not successful. The only possible solution was surgical reconstruction.

\section{Acknowledgements}

The case has been presented as poster in 19. SVK 2018.

\section{Conflict of interest}

None.

\section{Financing}

The work was supported by the grant SVV-2017 - 260372.

\section{Ethical statement}

We declare that the work was performed in compliance with all ethical standards.

\section{Informed consent}

We hereby declare that the patient had signed the informed consent at the time of admission to the hospital.

\section{References}

1. Kanabuchi K, Noguchi N, Kondo T. Vascular tracheobronchial compression syndrome in adults: a review. Tokai J Exp Clin Med 2011;36:106-111. 
2. Sebening $\mathrm{C}$, Jakob $\mathrm{H}$, Tochtermann $\mathrm{U}$, et al. Vascular tracheobronchial compression syndromes - experience in surgical treatment and literature review. Thorac Cardiovasc Surg 2000;48:164-174.

3. Wright PM, Alexander JP. Acute airway obstruction, hypertension and kyphoscoliosis. Anaesthesia 1991;46:119121.

4. Osinbowale OO, Bazan HA. Descending thoracic aortic aneurysm: case presentation and review. Postgrad Med 2014;126:68-75.

5. Erbel R, Aboyans V, Boileau C, et al., 2014 ESC Guidelines on the diagnosis and treatment of aortic diseases: document covering acute and chronic aortic diseases of the thoracic and abdominal aorta of the adult. The Task Force for the Diagnosis and Treatment of Aortic Diseases of the European Society of Cardiology (ESC). Eur Heart J 2014;35:2873926.

6. Lindsay ME, Dietz HC. The Genetic Basis of Aortic Aneurysm. Cold Spring Harb Perspect Med 2014;4:a015909.
7. Singh SM, Safi HJ, Estrera AL. Aortobronchial syndrome: extrinsic compression of the left main bronchus secondary to a descending thoracic aortic aneurysm. Ann Thorac Surg 2011;91:1292.

8. Kumar A, Dutta V, Negi S, Puri GD. Vascular airway compression management in a case of aortic arch and descending thoracic aortic aneurysm. Ann Card Anaesth 2016;19:568-571.

9. Sova M, Čtvrtlík F, Kuca I, Kolek V. Left main bronchus compression by massive thoracic aorta aneurysm as a cause of dyspnea, Cor Vasa 2015;57:e377-e380.

10. Abdul-Ghani A, Pisipati S, McWilliams R, Page RD. Aortobronchial fistula following aortic and bronchial stenting of thoracic aneurysm. Eur J Cardiothorac Surg 2006;29:419-421.

11. Madden BP, Loke TK, Sheth AC. Do expandable metallic airway stents have a role in the management of patients with benign tracheobronchial disease? Ann Thorac Surg 2006;82:274-278. 